\title{
A Study of the Quality Assessment of Accounting Degree Education in China
}

\author{
Hui $\mathrm{Lv}^{1,}$, Meijun Ning ${ }^{2}$, Zhangquan $\mathrm{Li}^{1}$, Qi $\mathrm{Li}^{1}$ \\ ${ }^{1}$ School of Economics and Management, China University of Petroleum (Beijing) \\ ${ }^{2}$ School of Economics and Management, North China University of Technology \\ *Corresponding author. Email: nmj@ncut.edu.cn
}

\begin{abstract}
From the perspective of deepening the cultivating of talents of accounting major in the new era, aiming at the undergraduate education and the master's education of accounting major in our country, this paper explains the promotion effect of teaching quality assessment and educational administration quality certification on the teaching quality construction of accounting major from the aspects of the historical development of accounting major, the current problems in the cultivating of accounting talents, the purpose of the cultivating of accounting major talents, the planning and guidance of national policies, and the mature master's education experience in the United States.
\end{abstract}

Keywords: Professional Master's Degree, Academic Master's Degree, Accounting Education, Accounting Major of undergraduate.

\section{INTRODUCTION}

Accounting degree education, as an important branch of accounting, plays an irreplaceable role in promoting the advancement of accounting. Since Economic Reform and open up of 1978 , more than 40 years have passed, a gradual reforming process has happened in accounting itself. In the past 40 years, great achievements have been made in the construction and implementation of accounting standards, the reform of degree education and many other aspects, which have made outstanding contributions for the progress of society and the rise of our economy of china. According to the relevant data of the Ministry of Education in official website, as of June 30, 2020, there were 2,688 universities (including independent colleges) in the country. There were 703 undergraduate majors among all the universities, and there are 639, 703 and 180 universities with accounting, financial management and auditing majors respectively. There are 162 institutions of higher learning in the secondary disciplines for master degree in accounting (academic research), 268 institutions for MPAcc education and 72 institutions of higher learning in the secondary disciplines for doctor degree in accounting.

With the social division of labour is becoming more and more refined, the professional level and technology of occupation is upgrading. And with the development of the industry, senior professional talents are required to have the following characteristics: the great practical ability as well as independent working ability. However, the Accounting Major of undergraduate with "wideranging and simple" Cultivation Model and Accounting Major of academic postgraduates and doctor with focusing on academic Cultivation Model cannot satisfy the demand of society for high-level talents of accounting. In the face of the background that the Cultivation Model of Accounting Academic Degree Education needs to be reformed and the cultivation quality needs to be improved, combined with the construction of Accounting Academic Degrees in domestic colleges and Universities, in order to promote the development of accounting discipline, evaluating the quality of Accounting Academic Degrees Education and proposing policies and proposals for transforming, upgrading and further development of Accounting major are profound significant research projects currently.

\section{THE CURRENT SITUATION OF ACCOUNTING DEGREE EDUCATION IN CHINA}

Since Economic Reform and open up of 1978, more than 40 years have passed, with the progress of the era and the change of the system, a gradual reforming process has happened in accounting itself. In the past 40 years, great achievements have been made in the construction and implementation of accounting standards, the recovery and development of CPA 
industry and many other aspects, which have made outstanding contributions for the progress of society and the rise of our economy of china. As an important branch of accounting, accounting academic degree education plays an irreplaceable role in promoting the progress of accounting. From 1966 to 1978, China's higher education almost collapsed, and the enrolment of accounting major was completely stopped due to the special historical background. With the opportunities brought by Economic Reform and open up, an unprecedented development has been happened in China's accounting education, which has experienced the stages of comprehensive recovery (1978-1985), reform and exploration (1986-1991), rapid development (19921999) and internationalization (2000-Now) [1].

\subsection{Undergraduate Education in Accounting}

In the past 40 years, China's accounting education has developed greatly in terms of educational system, educational levels, school running forms and teaching methods, and finally formed a diversified accounting education system [2]. (1)Education system. The education system has changed from the original single state-run government-led to the coexistence of state, private, Sino-foreign joint and other forms. Such kind of the change has not only made up for the lack of national funds for accounting education to a certain extent, and mobilized the enthusiasm of social forces to participate in accounting education, but also, more importantly, promoted the continuous improvement of China's accounting education system through the introduction of advanced foreign educational concepts, educational methods and school-running mechanisms. (2)Educational level. The level of accounting education has been continuously improved. Not only has the accounting education at the secondary, tertiary and undergraduate levels been developed in an all-round way, but also the education of master's degree and doctoral degree in accounting has been developed unprecedentedly. The diversity of accounting education levels satisfies the different demands of different levels of society. (3)Educational Form. The educational form has developed from the original single full-time ordinary higher education to the coexistence of ordinary, higher vocational, network, adult and follow-up education and other forms [3].

With the rise of knowledge economy, the speed of knowledge renewal is getting faster and faster. Under this situation, follow-up education, as an important supplement to academic education, has also been fully developed and greatly expanded through network education and other forms. In addition, the follow-up education of the accounting profession has also been incorporated into the daily accounting management. The diversification of accounting education not only provides a variety of alternative channels for training accounting talents, but also provides a flexible choice for the public to obtain accounting education in different space and time [4].

The survey shows that in the ranking list of the most popular majors and occupations for undergraduate students, accounting ranks first. Tt has increased a huge demand for undergraduate graduates in the accounting industry with the rapid development of society, which directly promotes the cultivating scale of accounting majors in colleges and universities. According to the relevant information released by the official website of the Ministry of Education and postgraduate recruitment websites, as of June 30, 2020, there were 2,688 universities (including independent colleges) in the country. There were 703 undergraduate majors among all the universities, and there are 639, 703 and 180 universities with accounting, financial management and auditing majors respectively. There are 162 institutions of higher learning in the secondary disciplines for master degree in accounting (academic research), 268 institutions for MPAcc education and 72 institutions of higher learning in the secondary disciplines for doctor degree in accounting.

\subsection{Postgraduate Education in Accounting}

With the continuous development of economic globalization, the market has put forward new requirements for high-level accounting personnel. They need to master relevant professional knowledge such as tax laws and regulations, have international vision and cross-cultural communication ability, be proficient in accounting business, be familiar with international market rules, and be able to participate in business strategies and management decisions of enterprises. [5]. Educational background can reflect the overall level of a professional team in one aspect, especially accounting profession, which requires high professional knowledge and judgment. Among the existing accounting personnel in our country, those with graduate degree or above account for a relatively small proportion, and there is a serious shortage of senior accounting personnel resources. In order to meet the market demand, it has become a new trend to train high-level accounting talents with master's degree in accounting. Since the resumption of postgraduate enrolment and the establishment of a degree system in 1979, the education of master's degree in accounting has developed rapidly. Up to 2020, there are 162 institutions of higher learning in the secondary disciplines for master degree in accounting (academic research), and 72 institutions of higher learning in the secondary disciplines for doctor degree in accounting.

\subsubsection{Academic Postgraduate Education}

In the 1980s, the cultivating task of master degree students in accounting was mainly to send teachers to 
colleges and universities, so the cultivating of master degree students in accounting has always been an academic cultivating model. However, with the development of China's economy and the surge of social demand for senior accounting talents, the employment direction of students of master degree in accounting has turned to government economic management departments and enterprises and institutions. Therefore, in the 1990s, the cultivating of master degree students in accounting in some colleges and universities has been gradually adjusted to both academic and applied model. With the further development of economy, the cultivating goal of master of accounting has changed into highquality, application-oriented and international accounting professionals with strong ability to discover, analyse and solve problems. The cultivating goal of academic master of accounting has led the enrolment object, curriculum setting, cultivating period, cultivating time, and so on the cultivating mode is inclined to oriented applied talents of the practical department.

And because of the lack of knowledge structure and ability training in solving practical problems, the graduate students cannot meet the demands of practical departments. Therefore, in the 21 st century, our country began to vigorously promote the development of professional degree, fully consider the demands of the actual departments in the curriculum and cultivating methods, and incline to the practical working demands in terms of knowledge structure and ability training, so as to meet the actual demands of the society and meet the requirements of the actual jobs for accountants to improve their professional level and professional standards [6].

\subsubsection{Professional postgraduate education}

In order to meet the needs of the continuous development of the market economy, the degree office of the State Council and the Ministry of Education formally established the MPAcc in 2004, and approved the pilot units in master of professional accounting in 2009, such as Renmin University of China, to start recruiting fulltime masters in accounting. After 17 years of development, the number of universities establishing MPAcc (professional master's degree) in our country has expanded from the initial 21 professional degree pilot authorization points to the existing 268, and the corresponding professional master's degree training scale has also increased significantly. The rapid development of accounting degree cannot be separated from the contribution of China National MPAcc Education Steering Committee, which is devoted to the education of accounting degree with Chinese characteristics.

On March 1, 2004, the Academic Degrees Committee of the State Council and the Ministry of Education issued the Academic Degrees [2004] No.3 document, formally announcing the establishment of China National MPAcc
Education Steering Committee, which is mainly responsible for the education guidance, supervision, research, consultation and other work in master of professional accounting. The inaugural meeting and the first meeting of China National MPAcc Education Steering Committee was held in Beijing, hosted by Beijing National Accounting Institute. On April 30, 2004, the Academic Degrees Committee of the State Council issued Document No.28 [2004] of the Academic Degrees Office, approving 21 postgraduate training units to carry out the pilot work of education in master of professional accounting, and agreeing that Beijing National Accounting Institute, Shanghai National Accounting Institute and Xiamen National Accounting Institute should carry out the pilot work of education in master of professional accounting in a joint cultivating mode with Tsinghua University, Shanghai University of Finance and Economics and Xiamen University respectively.

After the establishment of China National MPAcc Education Steering Committee and its secretariat, in accordance with the requirements of the Degree Committee of the State Council, the Ministry of Education and the Ministry of Finance, the Committee took "standardizing the training process and improving the training quality" as its central task, took "standardization, guidance, evaluation and supervision" as its working policy and "service, coordination, research and feedback" as its working focus, sought development in the reform, sought innovation in the development, and actively explored and carried out degree education of accounting major with Chinese characteristics.

The degree education of accounting has been highly valued by relevant departments. The leaders of the Academic Degree Office of the State Council and the Ministry of Education have participated in the plenary meetings and the working meetings of the training units of China National MPAcc Education Steering Committee for many times. They have also attended China MPAcc Students Case Competition, provided guidance for the MPAcc education, and entrusted and funded the China National MPAcc Education Steering Committee to organize and carry out research on education-related topics in master of professional accounting. China Academic Degrees and Graduate Education Development Center (CDGDC) actively supports the promotion of MPAcc case teaching, and cooperates with China National MPAcc Education Steering Committee to jointly build a teaching case base. The leadership of the degree office attended and delivered a speech at China MPAcc Students Case Competition, and the degree and postgraduate education development center of the Ministry of Education cooperated with MPAcc Education Steering Committee and funded the activities of China MPAcc Students Case Competition; The Department of Degree Management and Graduate Education of the Ministry of Education has funded and 
supported the deepening of the comprehensive reform of graduate education for accounting majors.

The Ministry of Finance, as the competent department of the accounting industry, also attaches great importance to the development of the accounting degree education. The chairman of MPAcc Education Steering Committee has always been the head of the accounting department of the Ministry of Finance; The Ministry of Finance has included the degree education of accounting major in the construction project of applied advanced accounting discipline, which has become one of the six major projects in the construction of accounting personnel team. The Accounting Department of the Ministry of Finance has set up a national education and guidance center for graduate students majoring in accounting. Its main functions include promoting the supervision, guidance and coordination of the education of graduate students majoring in accounting by the department in charge of the accounting industry, promoting the formulation of relevant policies for the education of graduate students majoring in accounting, the certification of educational quality and the interface with professional qualification examinations, etc. It is also responsible for guiding the daily work of the secretariat.

Therefore, the degree education of accounting has developed rapidly in recent years and has formed a brand effect. During its 14 years of development in China, master of professional accounting Education has accumulated rich experience in running schools. A considerable number of training units have made outstanding achievements in the cultivation of highquality, applied and international accounting talents. It has become an important choice for students and social figures to achieve rapid improvement in their personal ability and break through the bottleneck of career development. It has been widely recognized by the society and has enrolled more than 50,000 students nationwide up to now. Since 2012, MPAcc has become the second largest category of professional degree after MBA. In 2013, the registration ratio of full-time MPAcc reached 7:1, the popularity of applying for MPAcc has been increasing, and the quality of students has also been greatly improved. The graduates are highly recognized by the employer. Many large enterprises and government agencies have signed strategic cooperation agreements with the MPAcc training units. Studying MPAcc has become an important way to train and select high-level accounting management personnel in enterprises or government agencies. The brand of MPAcc education has been deeply rooted in the hearts of the people.

\section{EDUCATIONAL QUALITY ASSESSMENT OF ACCOUNTING UNDERGRADUATE EDUCATION IN CHINA}

The accounting profession has remained hot for many years, but the problems in its development process should not be underestimated: accounting education lacks strategic considerations for the overall development of accounting higher education; Professional education is mostly based on the scale of heroes, and the development of the connotation of winning by quality is relatively lagging behind, lack of necessary evaluation or highlevel certification; Lack of a proficient professional education system that can integrate education, teaching, academic research and practical activities;[7]Lack of the holistic awareness and actions to improve the level of professional education through collaborative development with other disciplines or professions; Lack of the use of modern technology and Internet technology to innovate the concepts, ideas, and methods of educational reform, and provide the best professional learning and practical user experience; Lack of international education and academic research closely integrated with local practice, etc.

Based on the above problems, accounting higher education needs to change the development and evaluation methods. All colleges and universities that apply for the establishment of accounting majors or newly established accounting majors should be the objects of evaluation, and they should conduct return visits after graduation of the first graduates, and regularly qualify evaluations. Colleges with a certain history of running a major and aiming to make this major a highquality or high-level university should be the subject of certification. In order to ensure the development of higher education in accounting, evaluation should have certain prescriptive nature, and evaluation standards should have a threshold effect; Certification standards should be high, and a set of high standards and strict certification schemes should be used to measure the mission, strategy, teachers, and quality of the school Guarantee, student and employer satisfaction, etc., to promote the continuous progress of certification units. Certification standards should be based on the following principles: missiondriven strategy, strategic guidance measures, measures to ensure quality, quality must be evaluated, and improvement should be continuous. Certification should be a voluntary application, not mandatory.

Regarding the evaluation and certification standards, in accordance with the "National Medium and Long-term Education Reform and Development Plan Outline (20102020)" and "Several Opinions of the Ministry of Education on Comprehensively Improving the Quality of Higher Education" (Jiaogao [2012] No. 4), 2014 , The Ministry of Education initiated the development of national standards for undergraduate professional 
teaching quality in colleges and universities (Higher Education Department of the Ministry of Education: "Notice on Printing and Distributing "Conference Minutes on the Development of National Standards for Undergraduate Professional Teaching Quality in Colleges and Universities", Letter from the Department of Education [2014] number 22). It has been more than 4 years since the start of the research and development, and more than 5,000 experts and professors (including more than 50 academicians) have participated. The Ministry of Education has successively organized hundreds of work seminars and soliciting opinions. On January 30, 2018, the Ministry of Education A press conference was held to release the "National Standards for Undergraduate Professional Teaching Quality in Ordinary Colleges and Universities" (hereinafter referred to as "National Standards"), which is the first national standard for teaching quality in the field of higher education in China. The national standard embodies three principles: (1) Highlight the student center. From "teaching well" to "learning well"; (2) Highlight demand orientation. To meet the needs of economic and social development, and to effectively improve the goal achievement, social adaptability, condition assurance, quality assurance effectiveness and result satisfaction of talent training; (3) Highlight continuous improvement. Emphasize the establishment of a school quality assurance system, which organically combines normal monitoring and regular evaluation. The national standard also has three major characteristics: (1) There are both "rules" and "space". Unify the basic quality requirements and leave room for the development of characteristics; (2) There are both "bottom lines" and "goals". "Guarding the bottom and not capping the top" not only requires the bottom line and the qualification, but also encourages the pursuit of excellence; (3) There are both "qualitative" and "quantitative". It not only puts forward qualitative requirements for various professional standards, but also contains necessary quantitative indicators. At the same time, the national standard proposes three promotions: promote reform with standard, promote construction with standard, and promote strong with standard.

The "National Standard" covers all 92 undergraduate majors and 703 majors in the catalogue of undergraduate majors in colleges and universities, involving more than 56,000 majors in colleges and universities across the country. As a result, the "National Standards for the Teaching Quality of Accounting for Undergraduate Majors" (Hereinafter referred to as the "National Standards for Accounting") was also officially released.

\section{EDUCATIONAL QUALITY ASSESSMENT OF ACCOUNTING PROFESSIONAL POSTGRADUATE EDUCATION IN CHINA}

As mentioned earlier, our country's accounting master's education is divided into two types: academic degrees and professional degrees, with the development and change of the social and economic environment, the scale of academic degree enrolment has been shrinking, the development of professional degrees has continued to grow. The evaluation often refers to the evaluation of undergraduate degree education, professional degrees have achieved rapid development in recent years and have a certification system tailored to their own characteristics. Therefore, the quality evaluation of academic master's degree education in this section will not be repeated, and the discussion will focus on the quality certification of professional degree master education.

Since 2004, the scale of MPAcc education has increased sharply. Due to the uneven quality of training of various training units, many problems have been exposed in the training of MPAcc talents in our country, such as fuzzy training objectives, outdated training methods, and unreasonable curriculum settings. These problems have severely restricted the innovation consciousness, practical ability and personality development of the Master of Accounting.[8]For the long-term development of our country's MPAcc education, quality control should always be the first lifeline, and training units should be guided to make full use of internal and external resources to formulate development strategies and talent training goals that suit their own characteristics, and improve students' comprehensive quality through system construction and project quality control And the quality of training, promote the sustainable development of our country's accounting professional degree education, and promote the continuous improvement of the accounting professional degree education level. Promote the quality certification of the master's degree in accounting, carry out quality certification, and build a reasonable competition mechanism for the survival of the fittest. [9]

The development of American master's education and the development of evaluation and certification are relatively mature, which is worth learning from our country. In the 1960s, AIC-PA began the study of improving the ability of accountants. The Horizon for Profession was released in 1967 and the Academic Preparation for Professional Accounting Career was released in 1968, have an important influence on the determination of American accounting education goals and even the setting of courses. In 1989, the American Accounting Association (AAA) established the Accounting Education Reform Committee (AECC) with the funding of the "Big Eight". With the support of the 
American Accounting Association, colleges and universities have carried out active teaching innovation activities and gradually developed in the direction of characteristic.[10]The most authoritative accredited rating agency for accounting education in the United States is the American Association of Business Schools (AACSB), which has an important influence on the accreditation and evaluation of business schools or business schools and accounting programs or accounting departments.[11] An objective and fair ranking not only has a certain reference value for students to choose schools and employing units to select talents, but also can promote competition among colleges and universities, and become their driving force for continuous improvement of teaching methods and quality of teaching. It can be seen that professional organizations and social intermediary evaluation agencies have played an important role in the development of American accounting master's education. [12]

In our country, the current accounting master's degree education steering committee is the professional organization of the national accounting master's degree education, which is responsible for guiding and coordinating the national accounting master's degree education activities. Under the guidance of the education authority and the accounting industry authority, the Accounting Education and Steering Committee has conducted a review of the Master of Accounting in accordance with the "Outline of the National Medium and Long-term Education Reform Plan" and the "Outline of the 13th Five-Year Plan for Accounting Reform and Development (2016-2020)". The requirements for professional degree development, combined with the actual development of professional degree education, and related accounting industry organizations and training units, jointly build a professional accounting professional degree education quality certification system (the full name is Accreditation for Accounting Professional Education Quality, hereinafter referred to as AAPEQ). The Education Steering Committee continues to conduct a comprehensive evaluation of the current status and development prospects of the accounting professional degree education of relevant training units, and gives a rating of the certification conclusion.

The National MPAcc Education Steering Committee Accounting Professional Master's Quality Certification has the characteristics of originality, internationalization, standardization and openness. It fills up the gaps in the quality certification of domestic accounting master's programs, draws on international advanced education concepts and certification experience, and establishes a set of quantifiable Standard quality certification system, at the same time encourage all training units to open schools, that is, to determine unique and diversified goals, self-determine project training goals and continue to work hard for them. Carrying out the quality certification of accounting master's degree can not only provide standards and quality guarantee for my country's accounting master's education, but also guide the development direction of accounting master's degree to meet the needs of high-level accounting talents in my country. [13]

\section{CONCLUSION}

The quality evaluation of accounting undergraduate degree education and the certification of accounting master degree education will become a powerful fulcrum for improving the quality and efficiency of accounting degree education in our country. The promulgation and implementation of the "National Standards for Teaching Quality of Undergraduate Majors in Accounting" and the "13th Five-Year Plan for Accounting Reform and Development (2016-2020)" have effectively held the "Niubi" and realized the quality of education and education. The substantial breakthrough of education quality certification has injected new impetus into the sustainable development of accounting undergraduate education and master's education in accounting in the new era.

The "National Standards for the Teaching Quality of Accounting Undergraduate Majors" and the "13th FiveYear Plan for Accounting Reform and Development (2016-2020)" are aimed at the characteristics of the needs of high-level applied professionals, in terms of system construction, it pays more attention to training quality as the core. From the three levels of "teaching, learning and doing", a three-dimensional system structure of "teaching quality", "learning quality" and "career development quality" has been constructed. from the three levels of "teaching, learning, and doing", a three-dimensional system structure of "teaching quality", "learning quality" and "career development quality" has been constructed. More emphasis is placed on "learning by doing", "learning by doing", "learning by doing, how can we do better", focusing on practical innovation ability and the quality of practical education, strengthening the important position of practice in talent training. Pay attention to process evaluation, highlight the increment of effectiveness, and tend to comprehensive evaluation, professionalism and accuracy of level evaluation, and form a new quality evaluation and certification system that is systematic, holistic and synergistic. For the construction of professional degrees, this system can objectively reflect the true quality level of professional degree authorization points. Taking the practical ability, innovation ability and professional competence of students as the core considerations to meet the fundamental needs of students for growth and development and all-round development as the premise, the comprehensive evaluation of the effectiveness of professional degree talent training is an innovative measure of professional degree level evaluation. 


\section{REFERENCES}

[1]. Y.Z. Liu, GH. Chi, The Appraisal of Chinese Accounting Education Reform of 30 Years Achievements, Problems \& Strategies[J]. Accounting Research, (08):pp.11-17, 2008.

[2]. Y.Z. Liu, GG. Sun The Current Situation and Countermeasures of Accounting Education and Accounting Education Research in China[J]. Accounting Research, (02):pp.75-81, 2004.

[3]. L. Chen Research on Undergraduate Accounting Education in China[D]. Dongbei University of Finance \& Economics.53,2005

[4]. C.D. Xiang A Probe into the Reform of Training Master of Accounting Major in the New Era[J]. Communication of Finance and Accounting, 2021, (03), pp.167-171 DOI:10.16144/j.cnki.issn10028072.2021. 03.034

[5]. X.Z, Tian. J. Zhang. On the Development Path of Professional Degree Postgraduate Education in China[J]. Continuing Education, (02):pp.32-34. DOI:10.13981/j.cnki.cn11-3315/g4.2012.02.011

[6]. Y. Chen, XR. Tie The Research Status Quo and Trend of Professional Degree Education inChina: From the perspective of bibliometrics (2000-2020) [J]. Journal of Graduate Education, pp. 2021, (02), 61-67 DOI:10.19834/j.cnki.yjsjy2011.2021.02.10.

[7]. Q. Liu, Does college accounting education attach importance to the cultivation of students' professional quality, in: Papers of the Second Lixin Accounting Symposium, 2007.

[8]. Y.H. Wang, Research on MPACC Major Enrollment Expansion, in: Fortune Today (China Intellectual Property), 2020, pp. 186-187.

[9]. J.B. Song, X. Jing, H.C. Wang, Carry out research on the education quality certification of Master of Accounting (MPAcc), in: Accounting Research, 2012, pp. 11-20.

[10].X.H. Qiu, The Situation and Enlightenment of American Professional Accounting Master's Education, in: Degree and postgraduate education, 2003, pp. 37-41.

[11].X.X. Zhou, Effective Linkage of Professional Degree Education and Professional Qualifications in the U.S. and Its Enlightenment, in: Journal of Lanzhou Institute of Education, 2015, pp. 66-68.

[12].New York State Education Department. CPA License Requirements. [EB/OL]. http://www.opnysed. gov/cpalic.htm, 2016-03-01.
[13].F.F. Zhang, The Realistic Dilemma and Countermeasures of the Link between Professional Degree Postgraduate Education and Professional Qualification Certification, in: Science Education Magazine (Early Issue), 2013, pp. 57-58. 